\title{
Botany \\ Pollen-Mediated Gene Flow in isolated AND CONTINUOUS STANDS OF BUR OAK, QUERCUS MACROCARPa (FAGACEAE) ${ }^{1}$
}

\author{
Kathleen J. Craft ${ }^{3}$ And Mary V. Ashley ${ }^{2}$ \\ Department of Biological Sciences, 845 W. Taylor St., M/C 066, University of Illinois at Chicago, Chicago, Illinois 60607 USA \\ - Premise of the study: Pollination patterns determine the reproductive neighborhood size of plants, the connectivity of popula- \\ tions, and the impacts of habitat fragmentation. We characterized pollination in three populations of Quercus macrocarpa oc- \\ curring in a highly altered landscape in northeastern Illinois to determine whether isolated remnant stands were reproductively \\ isolated. \\ - Methods: We used microsatellites to genotype all adults and 787 acorns from two isolated savanna remnants and a stand in an \\ old-growth forest. One isolated remnant occurred in a highly urbanized/industrialized landscape, and one occurred in an agri- \\ cultural landscape. Parentage assignment was used to assess pollen-mediated gene flow. \\ - Key results: Pollen donors from outside the study sites accounted for between $46 \%$ and $53 \%$ of paternities and did not differ \\ significantly among sites, indicating that similar high levels of gene flow occurred at all three sites. Within stands, the mean \\ pollination distance ranged from 42 to 70 meters, and when accounting for outside pollinations, mean pollination distances \\ were well over 100 meters. Genetic diversity of incoming pollen was extremely high in all three stands. The number of effec- \\ tive pollen donors, $\mathrm{N}_{\mathrm{ep}}$, calculated from paternity assignment was higher than that estimated by an indirect correlated paternity \\ approach. \\ - Conclusions: Our findings indicate that extremely isolated stands of oaks are unlikely to be genetically and reproductively \\ isolated, and remnant stands may contribute to maintaining genetic connectivity in highly modified landscapes.
}

Key words: microsatellites; oaks; paternity; pollen flow; pollination; Quercus

The genetic structure of plant populations is determined in large part by the movement of pollen within and among populations, and pollination patterns will shape population connectivity and gene flow. Understanding patterns of pollen-mediated gene flow across fragmented landscapes is important for predicting the impacts of landscape alterations on reproduction (Robledo-Arnuncio et al., 2004; Garcia et al., 2005), regeneration (Meiners et al., 2002; Finkeldey and Ziehe, 2004), and evolutionary processes (Foré et al., 1992) of plant populations. Patterns of pollen- and seed-mediated gene flow may be inferred indirectly by measuring population genetic structure (Berg and Hamrick, 1995; Bacles et al., 2004; Boys et al., 2005). This approach is limited, however, in that it provides only an estimate of historical levels of gene flow, and it generally does not partition gene flow into that effected by seeds and by pollen unless maternal and paternal markers are available. Given that many plant populations have been subject to very recent and drastic alterations of habitat, elucidating ongoing

\footnotetext{
1 Manuscript received 18 December 2009; revision accepted 13 October 2010.

The authors thank Dr. D. Nyberg for field and logistic assistance, J. Schlensker for field and technical assistance, and A. Carvlin, K. DervisWatson, and R. Kaneria for field and laboratory assistance. This manuscript was completed in partial fulfillment of the doctoral degree from the Graduate College at the University of Illinois at Chicago to K.J.C. This project was funded in part by a Provost's Award from the University of Illinois at Chicago to K.J.C.

2 Author for correspondence (e-mail: ashley@uic.edu); telephone: +1312-413-9700; fax: +1-312-413-9462

3 Current address: Department of Natural Sciences, 7400 Augusta Drive, Concordia University, River Forest, Illinois 60305-1499 USA
}

doi:10.3732/ajb.0900390 pollination patterns is critical for understanding the contemporary dynamics of plant populations.

Studies of contemporary pollen movement have been aided by the application of DNA microsatellite markers, which allows the direct assignment of a single pollen donor to a large proportion of sampled seeds or seedlings (Ashley, 2010). Genotyping seeds and assigning paternity to a single candidate father provides a direct means to resolve long-standing questions about pollination patterns, distances, and the shape of pollen dispersal curves. The picture of pollen dispersal that is emerging from such paternity studies conducted over the past $15 \mathrm{yr}$ has yielded a number of surprising findings that contradict traditional views of pollen dispersal (Ashley, 2010). In species ranging from wind-pollinated oaks (Dow and Ashley, 1996, 1998a, b; Streiff et al., 1999), to fig trees pollinated by small host-specific wasps (Ahmed et al., 2009), to bird- and insectpollinated cactus (Otero-Arnaiz et al., 2005), pollen dispersal rates generally have been found to be quite high. Effective pollen movement tracked by paternity assignment commonly occurs over surprisingly long distances, from hundreds of meters up to $160 \mathrm{~km}$ for the African fig, Ficus sycomorus (Ahmed et al., 2009). Furthermore, several studies have reported that habitat alteration and fragmentation actually may enhance pollen-mediated gene flow (White et al., 2002; Dick et al., 2003; Bacles et al., 2005; Byrne et al., 2007, 2008; Ottewell et al., 2009), contrary to traditional views that isolation and forest fragmentation will lead to inbreeding and reproductive isolation (Kramer et al., 2008).

Quercus macrocarpa is a monoecious, wind-pollinated, temperate tree species that is a key component of the prairie/ savanna ecosystem. In Illinois, oak savannas and prairie communities were established approximately $5000 \mathrm{yr}$ ago and were maintained by periodic drought and fire until European settlement (Anderson, 1991; Abrams, 2003). The Public Land Survey 
(PLS) conducted in this region from the 1820 s to the 1840 s has been used to reconstruct vegetation patterns at the time of European settlement (Bowles et al., 1994; Bowles and McBride, 2002). At that time, approximately $80 \%$ of the landscape was treeless prairie, with areas of timber making up less than $20 \%$ of the total (Bowles et al., 1994). Fire-resistant bur oak occurred in scattered prairie groves, as well as in continuous forests, growing on the east banks of rivers where the rivers served as firebreaks. Despite the isolation of these scattered groves across the landscape, they are not genetically differentiated (Craft and Ashley, 2007). Bur oaks still exist at low densities in isolated savannas as well as in continuous forests in the highly modified landscape of northeastern Illinois and the Chicago region, a situation that allowed us to examine pollen movement in bur oaks occurring in very distinct ecological settings. Previous findings based on acorn paternity assignments in a single stand of bur oaks showed that the majority of pollen came from trees outside the stand, and pollen movement within the stand was nearly random (Dow and Ashley, 1998a). In this study, we expand previous work on Q. macrocarpa (Dow and Ashley, 1996, 1998a, b) by studying pollination patterns at sites with high human impact. We studied extremely small and isolated stands of bur oak, one completely surrounded by urban development on the south side of Chicago, and one surrounded by an intensive agricultural landscape southwest of the city. These sites are more isolated than those where previous studies of oak pollination patterns have been undertaken (Dow and Ashley, 1996; Streiff et al., 1999; Valbuena-Carabaña et al., 2005; Nakanishi et al., 2009; Pluess et al., 2009), and the surrounding landscape is more highly affected by human activity. We compared pollen-mediated gene flow at these two sites with those at a relatively intact forest remnant that is part of the Forest Preserve District of Cook County. We evaluated whether the amount and genetic diversity of incoming pollen was diminished in two isolated stands relative to that in an extensive woodland and whether the type of matrix (urban or agricultural) influenced these patterns. Pollination patterns revealed in this study are relevant to the understanding of the genetic consequences of forest fragmentation and the potential for reproductive isolation of remote remnant stands of wind-pollinated trees.

We sampled and genotyped adult trees and assigned paternity to acorn crops of several trees at each site. We used two methods of paternity assignment (strict exclusion and maximum likelihood) to assess pollination patterns within each stand and to measure the extent of gene flow via pollen immigration into each stand. Genotyping errors, null alleles, and mutations can lead to false exclusions (type II errors) in parentage assignment when using strict exclusion. Likelihood-based methods as implemented in programs such as CERVUS (Marshall et al., 1998) are better able to accommodate type II errors, but they are sensitive to input estimates of the proportion of candidate fathers sampled, a value that is generally unknown (and of primary interest) in pollination studies (Ashley, 2010). We also used an indirect approach to examine correlated paternity within the pollen pools sampled by different mothers, and we used this analysis to calculate the effective number of pollen donors $\left(\mathrm{N}_{\mathrm{ep}}\right)$ (Smouse et al., 2001). We compared $\mathrm{N}_{\mathrm{ep}}$ values from the correlated paternity approach with those calculated directly from paternity assignments to test the accuracy of the indirect methods in sampling schemes like ours because indirect methods have become increasingly popular due to the requirement of fewer samples and fewer marker loci compared with direct approaches of paternity assignment.

\section{MATERIALS AND METHODS}

Study species - Quercus macrocarpa Mich., bur oak, is a species of oak in the white oak group that occurs throughout the Midwestern United States and southeastern Canada. It is found in both mixed forests and isolated stands and in Illinois is most commonly associated with open oak savannas. This species has the largest acorns of all North American oaks.

Study sites and leaf sampling-Adult trees were sampled at three sites in northeastern Illinois: Burnham Prairie Nature Preserve, Cranberry Slough Nature Preserve, and Goose Lake Prairie State Natural Area. Burnham Prairie is approximately $28 \mathrm{~km}$ from Cranberry Slough and $73 \mathrm{~km}$ from Goose Lake Prairie, whereas Cranberry Slough and Goose Lake Prairie are separated by $55 \mathrm{~km}$. See Craft and Ashley (2007) for a map of the study sites.

The sampling area at all sites was approximately one hectare. As mentioned earlier, two of the sites, Burnham Prairie and Goose Lake Prairie, are isolated single-species stands of bur oak located on fragments of remnant prairie. Burnham Prairie covers approximately 24.3 hectares in Chicago's Calumet region and is surrounded by railroad yards and residential and industrial development. The stand of bur oaks is separated by more than 200 meters from the nearest scattered bur oaks, and there are no nearby woodlands. Goose Lake Prairie is in Grundy County, approximately $80 \mathrm{~km}$ southwest of Chicago, and is the largest prairie remnant left in Illinois. Goose Lake Prairie covers $1,027.5$ hectares of land and is surrounded by a largely agricultural landscape. The small stand of bur oaks at Goose Lake Prairie is at least 500 meters away from the nearest bur oak, and there are no extensive woodlands nearby. All adult trees were sampled in the isolated stands, 26 at Goose Lake Prairie, and 62 at Burnham Prairie.

Cranberry Slough is a 150.7-hectare stretch of mixed oak-hickory forest, peat bogs, and swamps that is part of the 5670-hectare Palos Park Forest Preserve District in Cook County, Illinois. The 115 adult trees sampled at Cranberry Slough were interspersed with several other tree species, including Quercus alba (white oak), Carya ovata (shagbark hickory), and Quercus rubra (red oak). All trees were tagged and mapped using a Cartesian coordinate system. Distances between all pairs of trees at each site were determined on the basis of each tree's $(x, y)$ coordinates.

Acorn sampling and processing-Mature acorns were sampled directly from 9, 10, and 13 maternal trees at Burnham Prairie, Goose Lake Prairie, and Cranberry Slough, respectively. Acorns were collected at Burnham Prairie in September 2000, at Goose Lake Prairie in September 2001, and at Cranberry Slough in October 2003. Acorn crops varied among maternal trees, and 17 to 35 acorns were sampled from each maternal tree. Caps, pericarps, and seed coats were removed from each acorn manually and were discarded. Processed acorns were then pulverized to a smooth paste between two sheets of aluminum foil with use of a pestle. The acorn paste was placed in $1.5-\mathrm{mL}$ microfuge tubes and stored at $-80^{\circ} \mathrm{C}$ until DNA extraction.

Sample processing and DNA extraction-For extraction of DNA from leaves, approximately $1 \mathrm{~g}$ of leaf material was ground to a fine powder in liquid nitrogen and was then stored at $-80^{\circ} \mathrm{C}$ until extraction. Extractions were performed according to Keim et al. (1989), followed by additional purification with use of the Qiagen DNA Mini Kit (Qiagen, Venlo, Netherlands). This latter step was performed to remove contaminants such as tannins, pigments, and other polymerase chain reaction inhibitors. DNA was stored in sterile, deionized water and diluted to approximately $0.2-0.4$ $\mu \mathrm{g} / \mu \mathrm{L}$.

For extraction of DNA from acorns, approximately half of each acorn was used for each extraction. Extraction was performed with a modified high-salt CTAB protocol followed by three phenol:chloroform:isoamyl alcohol extractions to remove residual proteins and tannins. DNA was stored in sterile, deionized water and diluted to approximately $0.2-0.4 \mu \mathrm{g} / \mu \mathrm{L}$.

DNA genotyping - Five microsatellite loci were scored for this study. Three primers, MSQ13, MSQ4, and MSQ16, were developed for Q. macrocarpa by Dow et al. (1995) and two, QpZAG9 and QpZAG110, were developed for $Q$. petraea by Steinkellner et al. (1997). Polymerase chain reactions (PCRs) were performed with 0.2-0.4 $\mu \mathrm{g}$ genomic DNA, 200-500 $\mu \mathrm{M}$ dNTP, 0.15-0.6 $\mu \mathrm{M}$ primer, $2.0-3.0 \mathrm{mM} \mathrm{MgCl}, 1.0 \mu \mathrm{g} / \mu \mathrm{L}$ bovine serum albumin, PCR buffer (Promega Corporation, Madison, Wisconsin, USA), and 0.2 units Taq polymerase (Promega). One primer of each pair was end-labeled with a fluorescent 
$\operatorname{tag}(\mathrm{Cy}-3$, Fam, or Tet) (Integrated DNA Technologies, Coralville, Iowa, USA). Polymerase chain reactions consisted of a $94^{\circ} \mathrm{C}$ preheat followed by 38 cycles of $94^{\circ} \mathrm{C}$ denaturation for $30 \mathrm{~s}, 50^{\circ} \mathrm{C}-54^{\circ} \mathrm{C}$ annealing for $30 \mathrm{~s}, 72^{\circ} \mathrm{C}$ extension for $30 \mathrm{~s}$, and one $72^{\circ} \mathrm{C}$ extension for 5-10 min. Polymerase chain reaction products then were mixed with a fluorescent size standard, ROX 350 (Applied Biosystems, Carlsbad, California, USA), and were run on an MJ BaseStation automated sequencer (MJ Research, Waltham, Massachusetts, USA). All microsatellite alleles were scored using Cartographer software (MJ Research).

Paternity assignment-Paternity assignment was conducted by strict exclusion of multilocus genotypes. Because we sampled acorns directly from each tree, we had one known parent for each acorn. The known maternal component was subtracted from each offspring genotype, and the paternal component of each offspring genotype was compared with the genotypes of all adults to identify any genetically compatible pollen donors. If a maternal tree and acorn were heterozygous for the same alleles, candidate fathers were excluded if they had neither allele.

In addition to using strict exclusion, we determined parentage using the maximum-likelihood approach implemented by the program CERVUS (Marshall et al., 1998). CERVUS uses the observed multilocus genotypes in the data set to calculate a likelihood ratio for each candidate parent-offspring pair over all loci given the genotypic data of the population, and it calculates $\delta$, the difference in LOD (natural logarithm of the likelihood ratio) scores between the most likely parent, i.e., the candidate with the highest LOD score, and the second most likely parent. Confidence levels of $\delta$ are estimated through simulations of parental and offspring genotypes by using allele frequencies observed in the population; we used the $95 \%$ confidence level. Our input parameters for CERVUS included a $0.5 \%$ error rate over all five loci combined estimated by the number of mother-offspring mismatches, 10000 cycles, and $50 \%$ of candidate fathers sampled. The latter was based on previous studies of the mating systems of oaks (Dow and Ashley, 1996, 1998a, b; Streiff et al., 1999). CERVUS also was used to calculate descriptive statistics such as observed and expected heterozygosities and exclusion probabilities.

Pollination patterns inferred from paternity assignments-Both methods of paternity assignment indicated that trees located at unknown distances outside the stand sired a substantial portion of acorns at all three sites (see Results). For the subset of trees where the pollen donor was identified, we could characterize effective pollen movement within the stand. In this manner, within-stand pollination distances were calculated from distances between mapped fathers and maternal trees. Additionally, using a distance matrix based on the position of mapped trees, we determined the distances between all maternal trees and all other trees (potential pollinators) in 10-meter distance classes, including pollen donors identified through paternity assignments. We compared the distribution of pollen donors around maternal trees with the distribution of all adult trees at 10-meter intervals using Kolmogorov-Smirnov tests. If no relation exists between distance and pollinators, there should be no difference between the distributions of pollinations and the distributions of trees, i.e., pollinations are random in respect to distance from maternal tree. To examine and compare the genetic diversity of pollinations effected from inside and outside the stand, we calculated the number of alleles and the gene diversity represented in each pollen pool.

Correlated paternity and effective number of pollen donors-We calculated the correlated paternity among maternal sibships using the software package POLDISP 1.0c (Robledo-Arnuncio et al., 2007). Whereas the estimates of correlated paternity within and among maternal sibships can be used to estimate the distribution of the pollen dispersal distances (Robledo-Arnuncio et al., 2006), our sampling scheme was not appropriate for this application, which requires maternal trees to be spread across the landscape at varying distances from each other (our sampling comprised clustered trees at three sites separated by large distances). However, we wished to compare estimates of the probability of paternal identity (PPI) and the effective number of pollen donors, $\mathrm{N}_{\mathrm{ep}}$, using the indirect approach of correlated paternity with that of our direct approach based on parentage analysis. For the latter, we calculated PPI directly from the paternity assignments as the observed rate of paternal sharing, using the approach of Smouse and Robledo-Arnuncio (2005). We did this in two ways: one using only the within-stand assigned pollen donors, and the second using both the assigned and unassigned (outside) pollen donors. In the latter case, we assumed that each acorn pollinated by a tree outside the stand had a different father, as recommended by Smouse and Robledo-Arnuncio (2005).

\section{RESULTS}

Genetic analysis - Full (five-locus) genotypes were obtained for 752 acorns and 193 trees, whereas only four loci could be scored for 35 acorns and 10 trees. All loci were highly polymorphic, with a mean of 14.1 alleles averaged over all adults and all loci (Table 1). The mean observed heterozygosity for adults, 0.924 , was significantly higher than the mean expected heterozygosity, 0.852 (Table 1). Significance of heterozygote excess was determined by using randomization tests based on Wright's $\mathrm{F}_{\mathrm{IT}}$, implemented in FSTAT. This excess of heterozygotes is likely due to the absence of selfing in this species (Balloux, 2004), as has been noted in previous studies (Craft et al., 2002, Dutech et al., 2005). The total exclusionary power calculated by CERVUS for paternity assignment was 0.999 for Burnham Prairie, 0.997 for Goose Lake Prairie, and 0.998 for Cranberry Slough.

Parentage analyses-For all parentage analyses using strict exclusion, only male parents matching all five microsatellite loci were considered candidate parents. Of the 215 acorns genotyped at Burnham Prairie, 100 (46.5\%) had a genetically compatible male parent within the study site, whereas $115(53.5 \%)$ had no genetically compatible sire within the study site (Table 2). For individual maternal trees, the proportion of acorns assigned to fathers in the stand ranged from $18.2 \%$ to $56.5 \%$, and the number of assigned fathers ranged from 4 to 14 . All assigned acorns except two matched only one father at all five loci, whereas two acorns matched two different fathers within the stand at all loci. One of these acorns matched a father that had missing data for one locus but matched at the other four loci.

At Cranberry Slough, of the 347 acorns genotyped, 184 (53.0\%) had a genetically compatible male parent within the study site, whereas $163(47.0 \%)$ were sired by males outside the study site (Table 2). For individual trees, the range for withinstand pollinations was $41.4 \%-65.0 \%$, and the number of assigned fathers ranged from 10 to 19 . All assigned acorns except for 12 matched only one father at all five loci. Those twelve acorns matched two males within the stand at all five loci.

Table 1. Descriptive statistics. Significant values of $F_{I S}$, are shown in bold. Means were averaged across sites.

\begin{tabular}{lccccc}
\hline \hline \multirow{2}{*}{ Site } & Locus & $\begin{array}{c}\text { Number of } \\
\text { alleles }\end{array}$ & $H_{\mathrm{o}}$ & $H_{\mathrm{e}}$ & $F_{\text {IS }}$ \\
\hline Burnham Prairie & QpZag9 & 18 & 0.935 & 0.897 & -0.043 \\
& QpZag110 & 10 & 0.883 & 0.839 & $\mathbf{- 0 . 0 5 2}$ \\
& MSQ13 & 17 & 0.953 & 0.862 & $\mathbf{- 0 . 1 0 6}$ \\
& MSQ4 & 14 & 0.911 & 0.868 & $\mathbf{- 0 . 0 4 9}$ \\
Cranberry Slough & MSQ16 & 17 & 0.952 & 0.886 & $\mathbf{- 0 . 0 7 5}$ \\
& QpZag9 & 18 & 0.952 & 0.888 & $\mathbf{- 0 . 0 7 3}$ \\
& QpZag110 & 11 & 0.870 & 0.826 & $\mathbf{- 0 . 0 5 3}$ \\
& MSQ13 & 13 & 0.980 & 0.879 & $\mathbf{- 0 . 1 1 6}$ \\
Goose Lake Prairie & MSQ4 & 13 & 0.868 & 0.813 & $\mathbf{- 0 . 0 6 7}$ \\
& MSQ16 & 15 & 0.924 & 0.852 & $\mathbf{- 0 . 0 8 5}$ \\
& QpZag9 & 14 & 0.948 & 0.894 & $\mathbf{- 0 . 0 6 0}$ \\
& MSQ10 & 11 & 0.880 & 0.797 & $\mathbf{- 0 . 1 0 5}$ \\
& MSQ4 & 13 & 0.963 & 0.818 & $\mathbf{- 0 . 1 7 8}$ \\
Mean & MSQ16 & 18 & 0.896 & 0.772 & $\mathbf{- 0 . 1 6 1}$ \\
& & 14.067 & 0.947 & 0.894 & $\mathbf{- 0 . 0 5 9}$ \\
\hline
\end{tabular}

Note: $H_{\mathrm{o}}$, observed heterozygosity; $H_{\mathrm{e}}$, expected heterozygosity; $F_{\mathrm{IS}}$, average deviation in heterozygosity in adults from each site. 
TABLE 2. Pollination results by site. PPI $\left(\mathrm{D}_{\text {all }}\right)$ is the probability of paternal identity based on all the observed shared pollinations ("direct all"), and $\operatorname{PPI}\left(D_{w s}\right)$ is the probability of paternal identity using only the within-stand assigned pollen donors ("direct within stand") and their associated effective number of pollen donors, $1 / \mathrm{PPI}\left(\mathrm{D}_{\text {all }}\right.$ and $\left.\mathrm{D}_{\mathrm{ws}}\right)$. PPI(I) is within-sibship correlated paternity estimated with the indirect method implemented in PolDisp 1.0c (Robledo-Arnuncio et al., 2007), and the associated estimate of the effective number of pollen donors is $\mathrm{N}_{\mathrm{ep}}(\mathrm{I})$. All averages represent the means across maternal trees at each site.

\begin{tabular}{|c|c|c|c|c|c|c|c|c|c|}
\hline Site & $\begin{array}{c}\text { Maternal } \\
\text { trees }\end{array}$ & Acorns & $\begin{array}{c}\text { Within-stand } \\
\text { assignments (\%) }\end{array}$ & $\begin{array}{c}\text { Average PPI } \\
\left(D_{\text {all }}\right)\end{array}$ & $\mathrm{N}_{\mathrm{ep}}\left(\mathrm{D}_{\mathrm{all}}\right)$ & Average $\operatorname{PPI}\left(\mathrm{D}_{\mathrm{ws}}\right)$ & $\mathrm{N}_{\mathrm{ep}}\left(\mathrm{D}_{\mathrm{ws}}\right)$ & Average PPI(I) & $\mathrm{N}_{\mathrm{ep}}(\mathrm{I})$ \\
\hline Burnham Prairie & 9 & 215 & $100(46.5 \%)$ & 0.0140 & 71.3 & 0.050 & 19.9 & 0.116 & 8.62 \\
\hline Cranberry Slough & 13 & 347 & $184(53.0 \%)$ & 0.00727 & 137.5 & 0.020 & 49.8 & 0.102 & 9.80 \\
\hline Goose Lake Prairie & 10 & 225 & $104(46.2 \%)$ & 0.0217 & 46.1 & 0.1 & 10 & 0.125 & 8.00 \\
\hline
\end{tabular}

At Goose Lake Prairie, of the 225 acorns genotyped, 104 $(46.2 \%)$ had a genetically compatible male within the study site, whereas $121(53.8 \%)$ were sired by a male outside of the study site (Table 2). For individual trees, the range of withinstand pollinations was $19.4 \%-44.4 \%$, and the number of assigned fathers ranged from 5 to 10 . All assigned acorns except for six matched only one father at all five loci. Those six acorns matched two fathers at all five loci.

Our paternity assignments made using strict exclusion matched the most likely assignments made by CERVUS extremely well. Of the 787 acorns genotyped, $758(96.3 \%)$ had the same father assigned by the two methods. Twenty $(2.5 \%)$ of the acorns had two candidate trees that matched at all five loci, and CERVUS assigned one of the two fathers identified by strict exclusion. For the other nine cases $(1.1 \%)$, the most likely father identified by CERVUS mismatched the acorn at one or more loci, whereas strict exclusion assigned an adult tree that matched at all loci. Because of the close agreement between the two paternity methods, we chose to use the exclusion-based assignments for all subsequent analyses of pollination patterns.

The continuous forest site, Cranberry Slough, appeared to have a lower proportion of outside pollinations than the two isolated sites (Table 2); however, a $\chi^{2}$ test of heterogeneity $\left(\chi^{2}=3.45, \mathrm{df}=2, P=0.18\right)$ indicated that the proportions of outside pollinations among the sites were not significantly different.

Pollination patterns - We compared the distributions of assigned pollen donors around maternal trees with the distributions of all adult trees. The distribution of between-tree distances and pollination distances were compared using a KolmogorovSmirnoff test. At Burnham Prairie $(\mathrm{D}=0.048, P=0.99)$ (Fig. 1a) and Goose Lake Prairie ( $D=0.082, P=0.86)$ (Fig. 1c), the two distributions were not significantly different, indicating that maternal trees were pollinated by trees in the stand irrespective of their distance from the maternal tree. These distributions were significantly different at Cranberry Slough $(\mathrm{D}=$ $0.236, P=0.00$ ) (Fig. 1b), signifying a departure from random mating because the number of pollinations decreased with increasing distance from the maternal trees. The average withinstand pollination distances were $69.9 \mathrm{~m}$ for Burnham Prairie, $53.5 \mathrm{~m}$ for Cranberry Slough, and $42.2 \mathrm{~m}$ for Goose Lake Prairie. If we use $200 \mathrm{~m}$ and $500 \mathrm{~m}$ values for outside pollinations at Burnham Prairie and Goose Lake Prairie, respectively, on the basis of our minimum estimate of distance to the nearest bur oak outside the stand, the average pollination distance is $139.5 \mathrm{~m}$ for Burnham Prairie and $288.4 \mathrm{~m}$ for Goose Lake Prairie. These values are likely severe underestimates of the true average pollination distance because most outside pollinations were likely from more distant trees. We could not estimate the mini- mum average pollination distance for Cranberry Slough using distance to the nearest bur oak because the Cranberry Slough site was an arbitrarily delineated patch within a continuous forest.

Male reproductive success for pollinations effected within each stand is shown in Fig. 2. Whereas all trees except two at Goose Lake Prairie sired at least one acorn, a larger proportion of sampled adult trees at Cranberry Slough and Burnham Prairie did not sire any of the acorns sampled $(29.6 \%$ and $22.6 \%$, respectively). The relative male reproductive success at Goose Lake Prairie, the smallest and most isolated site surrounded by prairie and agricultural fields, was more skewed, with a larger proportion of trees siring multiple acorns. At both Burnham Prairie and Cranberry Slough, more than half the adult trees sired one or two acorns, though at Cranberry Slough, a single tree sired 10 acorns.

A comparison of genetic diversity for pollinations within each stand (assigned fathers) and from outside each stand revealed that at all three sites, more alleles were found in the unassigned fathers than in the assigned fathers, with the greatest difference at Goose Lake Prairie (47 vs. 62 alleles, Table 3). Relatively few alleles were unique to the assigned fathers compared with the unassigned fathers. For example, at Goose Lake Prairie, gene flow into the stand brought in 17 alleles not found in the within-stand pollen pool. The gene diversity $\left(H_{\mathrm{e}}\right)$ of both the assigned and unassigned fathers was consistently high, ranging from 0.798 to 0.872 , and no significant difference in gene diversity existed among the sites (Table 3 ).

Pollen pool analysis and effective number of pollen donors - The values of the probability of paternal identity, $\operatorname{PPI}\left(\mathrm{D}_{\text {all }}\right)$ and $\operatorname{PPI}\left(\mathrm{D}_{\mathrm{ws}}\right)$, were calculated from our measured rate of paternal sharing within sibships based on paternity assignments (Table 2), using the method of Smouse and RobledoArnuncio (2005). We consider PPI $\left(\mathrm{D}_{\text {all }}\right)$ to be the most accurate estimate, as it includes both within-stand pollinations and the outside pollinations, with each acorn pollinated from outside the stand assumed to have a different father. It seems unlikely that acorns from one tree would share a pollen donor hundreds of meters away. On the other hand, $\operatorname{PPI}\left(\mathrm{D}_{\mathrm{ws}}\right)$, which only considers the assigned within-stand pollen donors, can be considered a lower bound on the true PPI. We also calculated PPI from the indirect method of correlated paternity within sibships, PPI(I). Estimates of PPI $\left(D_{\text {all }}\right)$ were much higher than estimates of PPI(I) calculated indirectly (Table 2). For example, on the basis of paternity assignments, correlated paternity at Burnham Prairie was only 0.0140 , but it was estimated to be 0.116 by the indirect methods. Because the effective number of pollen donors, $\mathrm{N}_{\mathrm{ep}}$, is calculated as the inverse of PPI, the direct $\mathrm{N}_{\mathrm{ep}}$ estimates from paternity assignments were much higher than those 

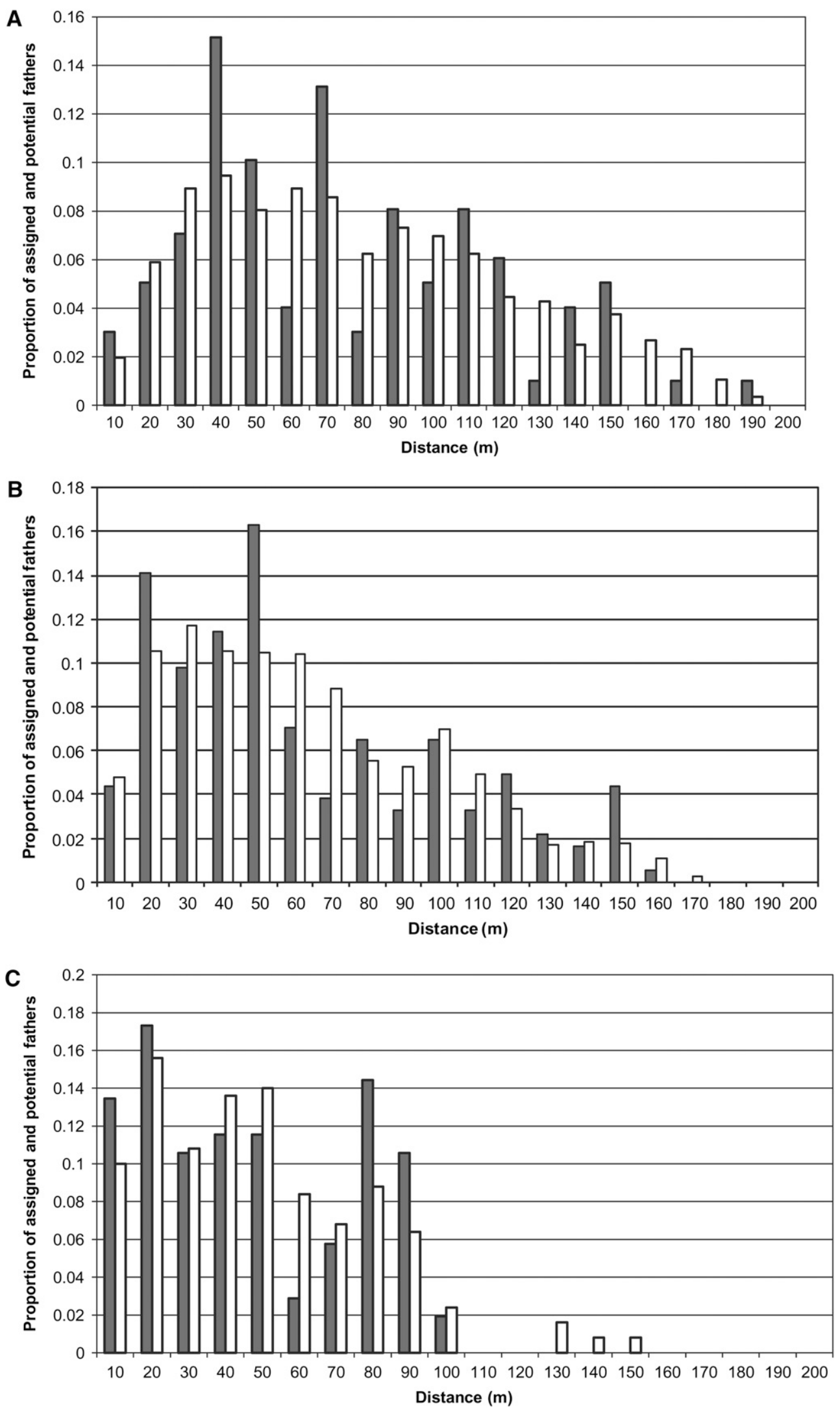

Fig. 1. Proportion of assigned (solid bars) and potential (open bars) pollen donors at each 10-m distance class from maternal tree. (A) Burnham Prairie; (B) Cranberry Slough; (C) Goose Lake Prairie. 


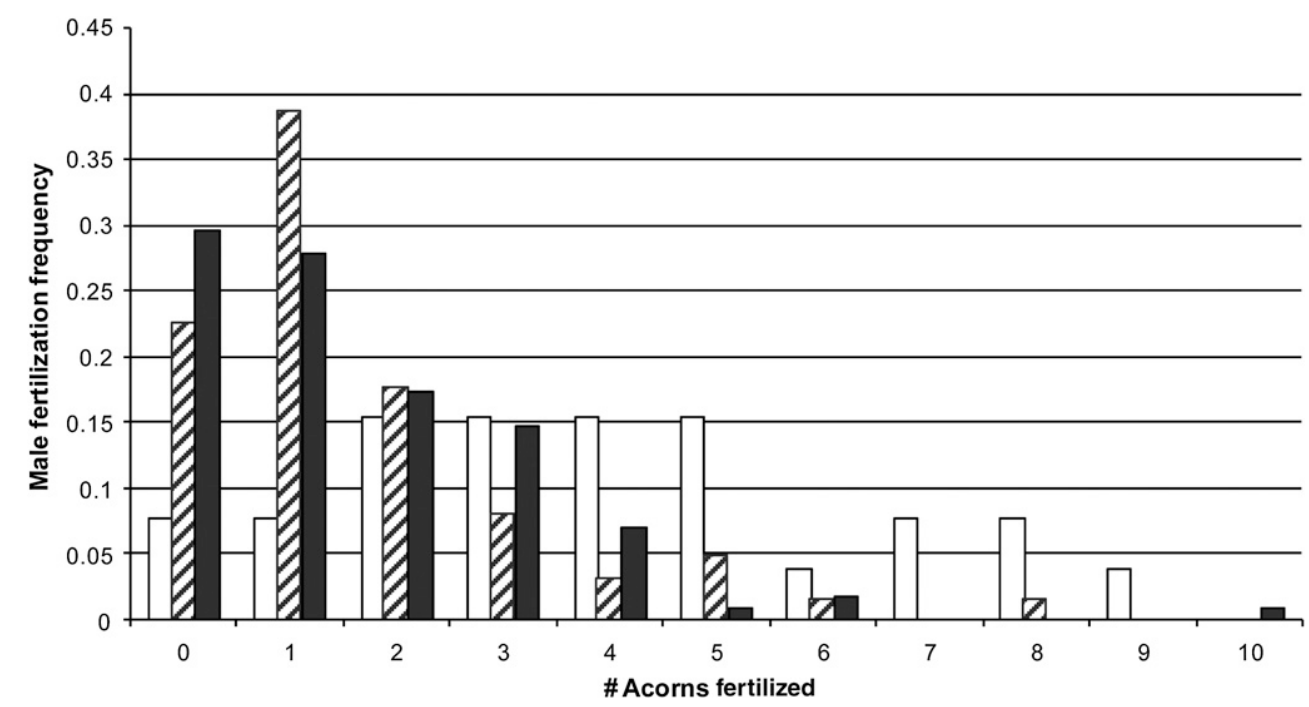

Fig. 2. Male reproductive success expressed as fertilization frequency at Goose Lake Prairie (open bars), Burnham Prairie (striped bars), and Cranberry Slough (solid bars).

calculated indirectly (Table 2). For example, at Burnham Prairie, the direct estimate indicated more than 71 effective pollen donors, compared with fewer than nine for the indirect method. The PPI $\left(D_{w s}\right)$ calculations also were higher than the indirect estimates, with the exception of Goose Lake Prairie, where the values were very similar.

\section{DISCUSSION}

Parentage analysis suggests that extremely isolated patches of $Q$. macrocarpa receive large amounts of pollen from distant sources, with males outside the stands fathering more than half the progeny at both Burnham Prairie and Goose Lake Prairie. Given that these two sites are quite remote, we conclude that high levels of long-distance pollination occur at both sites, and the differences in the surrounding landscape matrix did not dramatically alter pollen flow patterns. The findings for Burnham Prairie are particularly interesting because the surrounding area is a dense urban matrix comprising high-density residential areas, extensive rail yards, and a decaying industrial infrastructure. This setting differs from that of most forest fragmentation studies, where the matrix is typically agricultural row crops, pastures, or plantations. At Burnham Prairie, we see that pollen disperses well through a highly structured urban landscape.

To assess whether pollination patterns differ depending on the degree of isolation, we included a patch of trees within a continuous forest in our study. Our study included only three

TABLE 3. Total number of alleles in assigned pollen donors $\left(\mathrm{AP}_{\mathrm{T}}\right)$ and unassigned pollen donors $\left(\mathrm{UP}_{\mathrm{T}}\right)$, number of alleles unique to assigned pollen donors $\left(\mathrm{AP}_{\mathrm{U}}\right)$ and unassigned pollen donors $\left(\mathrm{UP}_{\mathrm{U}}\right)$, and average gene diversity in assigned $\left(\mathrm{A}_{\mathrm{He}}\right)$ and unassigned $\left(\mathrm{U}_{\mathrm{He}}\right)$ pollen donors. $H_{\mathrm{e}}$ is the gene diversity averaged across all 5 loci.

\begin{tabular}{lcccrcc}
\hline \hline Site & $\mathrm{AP}_{\mathrm{T}}$ & $\mathrm{UP}_{\mathrm{T}}$ & $\mathrm{AP}_{\mathrm{U}}$ & $\mathrm{UP}_{\mathrm{U}}$ & $\mathrm{A}_{\mathrm{He}}$ & $\mathrm{U}_{\mathrm{He}}$ \\
\hline Burnham Prairie & 58 & 67 & 5 & 14 & 0.848 & 0.885 \\
Cranberry Slough & 57 & 64 & 1 & 8 & 0.844 & 0.893 \\
Goose Lake Prairie & 47 & 62 & 2 & 17 & 0.798 & 0.872 \\
\hline
\end{tabular}

sites, with no replication of a continuous forest site. This limits our ability to conclude whether any differences are due to landscape differences or to other variation among sites. Whereas the forested site, Cranberry Slough, received less pollen from outside sources $(46.9 \%)$ than either isolated stand (Table 2), the differences were not statistically significant. The acorns at Cranberry Slough also were sired by a diverse array of pollen donors, with no pollen donor over-represented. Distances between maternal trees and known fathers were also similar at all sites, though they were lower at Goose Lake Prairie, the most isolated site. Thus, pollination patterns are similar among the sites with no striking significant differences among isolated and continuous forest stands.

In theory, paternity assignment should be the most direct approach to estimating the shape of the pollen dispersal kernel. Although our results clearly infer a "fat-tailed" dispersal kernel, they do not provide much new information about the shape of the long-distance component of the curve. This component, however, accounts for the majority of pollinations. Few paternity-based pollination studies have occurred on a scale large enough to infer the shape of the long-distance dispersal function. One exception is a recent study of black cottonwoods (Slavov et al., 2009) that reported the commonly used standard exponential power and Weibull functions both provided poor predictions of both local and long-distance pollination.

Within the stands, there is no or only a slight pollination advantage based on proximity (Fig. 1). At Burnham Prairie and Goose Lake Prairie, pollinations occurred irrespective of distance between trees. Clearly these trees do not generally rely on near-neighbor pollinations for their acorn crops, suggesting there may be factors other than distance that strongly influence pollination patterns. Differences in flowering phenology likely affect mating patterns, though there appears to be an additional mechanism that increases offspring diversity and average pollination distances in oak species (Craft et al., 2009). Trees undoubtedly receive larger amounts of pollen from trees in proximity and a smaller proportion from long-distance sources, yet this high proportion of near-neighbor pollen is not reflected in the progeny arrays. Many trees sired a small number of acorns (Fig. 2). Pollen from more distant trees may be preferential to 
pollen from near-neighbors. In fact, it has been suggested that maternal mate choice may occur in oaks (Dow and Ashley, 1998a; Boavida et al., 1999), and Craft et al. (2009) provide a possible model of mate choice based on selective embryo abortion.

With genetically diverse offspring in even the most isolated sites, and high levels of long-distance pollination commonly occurring over hundreds and perhaps thousands of meters, it is not surprising that this species persisted in scattered savannas for thousands of years with little evidence of genetic differentiation or genetic isolation (Craft and Ashley, 2007). High rates of pollen immigration in $Q$. macrocarpa are also supported by previous studies of both historic (Schnabel and Hamrick, 1990; Craft and Ashley, 2007) and contemporary (Dow and Ashley 1996, 1998a) gene flow, and similar patterns have been found in other oaks species globally (Streiff et al., 1999; Dodd and Afzal-Rafii, 2004; Muir et al., 2004; Chung et al., 2005). The ability of Quercus species to maintain genetic connectivity suggests this genus has likely experienced no substantial change in gene flow patterns over the last few thousand years despite increasing fragmentation due to anthropogenic changes. Even though woody, outcrossing species typically have higher genetic diversity and lower among-population genetic structure than nonwoody species (Hamrick and Godt, 1996), the genus Quercus may be quite remarkable in this regard.

Our results suggest that it is likely that bur oak, as well as other wind-pollinated trees, should be resilient to reproductive isolation resulting from habitat fragmentation. Concerns regarding the negative genetic consequences resulting from forest fragmentation may be overstated for many tree species (Kramer et al., 2008). Oak savannas are globally threatened ecosystems that have largely been lost from the Midwestern United States and require expanding conservation efforts. However, our results suggest that conservation managers should be less concerned about loss of genetic variation in oaks but rather should focus more on addressing ecological and demographic factors contributing to the continued decline of the savanna ecosystem.

\section{LITERATURE CITED}

Abrams, M. D. 2003. Where has all the white oak gone? Bioscience 53: 927-939.

Ahmed, S., S. G. Compton, R. K. Butlin, and P. M. Gilmartin. 2009. Wind-borne insects mediate directional pollen transfer between desert fig trees 160 kilometers apart. Proceedings of the National Academy of Sciences, USA 106: 20342-20347.

Anderson, R. C. 1991. Presettlement forests of Illinois. In Proceedings of the Oak Woods Management Workshop, 1991, 9-19. Eastern Illinois University, Charleston, Illinois, USA.

Ashley, M. V. 2010. Plant parentage, pollination, and dispersal: How DNA microsatellites have altered the landscape. Critical Reviews in Plant Sciences 29: 148-161.

Bacles, C. F. E., J. BurczyK, A. J. Lowe, and R. A. Ennos. 2005. Historical and contemporary mating patterns in remnant populations of the forest tree Fraxinus excelsior L. Evolution; International Journal of Organic Evolution 59: 979-990.

Bacles, C. F. E., A. J. Lowe, AND R. A. Ennos. 2004. Genetic effects of chronic habitat fragmentation on tree species: The case of Sorbus aucuparia in a deforested Scottish landscape. Molecular Ecology 13: 573-584.

Balloux, F. 2004. Heterozygote excess in small populations and the heterozygote-excess effective population size. Evolution; International Journal of Organic Evolution 58: 1891-1900.

Berg, E. E., AND J. L. Hamrick. 1995. Fine-scale genetic structure of a turkey oak forest. Evolution; International Journal of Organic Evolution 49: 110-120.
Boavida, L. C., M. C. Varela, And J. A. FeiJo. 1999. Sexual reproduction in the cork oak (Quercus suber L.). I. The progamic phase. Sexual Plant Reproduction 11: 347-353.

Bowles, M. L., M. D. Hutchison, AND J. L. McBride. 1994. Landscape pattern and structure of oak savanna, woodland, and barrens in northeastern Illinois at the time of European settlement, In J. S. Fralish, R. C. Anderson, J. E. Ebinger \& R. Szafoni [eds.] Proceedings of the North American Conference on Savannas and Barrens, 65-73. Environmental Protection Agency, Great Lakes national Program Office, Chicago.

Bowles, M. L., AND J. L. McBRIDE. 2002. Pre-European settlement vegetation of Cook County, Illinois, as recorded by the U.S. Public Land Survey. The Morton Arboretum, Lisle, Illinois, USA.

Boys, J., M. Cherry, and S. Dayanandan. 2005. Microsatellite analysis reveals genetically distinct populations of red pine (Pinus resinosa, Pinaceae). American Journal of Botany 92: 833-841.

Byrne, M., C. P. Elliott, C. Yates, and D. J. Coates. 2007. Extensive pollen dispersal in a bird-pollinated shrub, Calothamnus quadrifidus, in a fragmented landscape. Molecular Ecology 16: 1303-1314.

Byrne, M., C. P. Elliott, C. J. Yates, and D. J. Coates. 2008. Maintenance of high pollen dispersal in Eucalyptus wandoo, a dominant tree of the fragmented agricultural region in Western Australia. Conservation Genetics 9: 97-105.

Chung, M. Y., K. J. Kim, J. H. PAK, C. W. Park, B. Y. Sun, E. R. Myers, AND M. G. Chung. 2005. Inferring establishment histories in populations of Quercus dentata (Fagaceae) from the analysis of spatial genetic structure. Plant Systematics and Evolution 250: 231-242.

Craft, K. J., AND M. V. Ashley. 2007. Landscape genetic structure of bur oak (Quercus macrocarpa) savannas in Illinois. Forest Ecology and Management 239: 13-20.

Craft, K. J., M. V. Ashley, And W. D. Koenig. 2002. Limited hybridization between Quercus lobata and Quercus douglasii (Fagaceae) in a mixed stand in central coastal California. American Journal of Botany 89: 1792-1798.

Craft, K. J., J. S. Brown, A. J. Golubski, and M. V. Ashley. 2009. A model for polyandry in oaks via female choice: A rigged lottery. Evolutionary Ecology Research 11: 471-481.

Dick, C. W., G. Etchelecu, and F. Austerlitz. 2003. Pollen dispersal of tropical trees (Dinizia excelsa: Fabaceae) by native insects and African honeybees in pristine and fragmented Amazonian rainforest. Molecular Ecology 12: 753-764.

Dodd, R. S., AND Z. AfZAL-Rafir. 2004. Selection and dispersal in a multispecies oak hybrid zone. Evolution; International Journal of Organic Evolution 58: 261-269.

Dow, B. D., AND M. V. Ashley. 1996. Microsatellite analysis of seed dispersal and parentage of saplings in bur oak, Quercus macrocarpa. Molecular Ecology 5: 615-627.

Dow, B. D., AND M. V. Ashley. 1998a. High levels of gene flow in bur oak revealed by paternity analysis using microsatellites. Journal of Heredity 89: 62-70.

Dow, B. D., AND M. V. Ashley. 1998b. Factors influencing male mating success in bur oak, Quercus macrocarpa. New Forests 15: 161-181.

Dow, B. D., M. V. Ashley, AND H. F. Howe. 1995. Characterization of highly variable $(\mathrm{GA} / \mathrm{CT})_{\mathrm{n}}$ microsatellites in the bur oak, Quercus macrocarpa. Theoretical and Applied Genetics 91: 137-141.

Dutech, C., V. L. Sork, A. J. Irwin, P. E. Smouse, and F. W. Davis. 2005. Gene flow and fine-scale genetic structure in a wind-pollinated tree species, Quercus lobata (Fagaceae). American Journal of Botany 92: 252-261.

FinKeldeY, R., AND M. Ziene. 2004. Genetic implications of silvicultural regimes. Forest Ecology and Management 197: 231-244.

Foré, S. A., R. J. Hickey, AND J. L. Vankat. 1992. Genetic structure after forest fragmentation: A landscape ecology perspective on Acer saccharum. Canadian Journal of Botany 70: 1659-1668.

Garcia, C., J. M. Arroyo, J. A. Godoy, and P. Jordano. 2005. Mating patterns, pollen dispersal, and the ecological maternal neighbourhood in a Prunus mahaleb L. population. Molecular Ecology 14: $1821-1830$.

Hamrick, J. L., AND M. J. W. GodT. 1996. Effects of life history traits on genetic diversity in plant species. Philosophical Transactions 
of the Royal Society of London. B, Biological Sciences 351: 1291-1298.

Keim, P., K. N. Paige, T. G. Whitham, and K. G. Lark. 1989. Genetic analysis of an interspecific hybrid swarm of Populus: Occurrence of unidirectional introgression. Genetics 123: 557-565.

Kramer, A. T., J. L. Ison, M. V. Ashley, and H. F. Howe. 2008. The paradox of forest fragmentation genetics. Conservation Biology 22: $878-885$.

Marshall, T. C., J. Slate, L. E. B. Kruuk, and J. M. Pemberton. 1998. Statistical confidence for likelihood-based paternity inference in natural populations. Molecular Ecology 7: 639-655.

Meiners, S. J., S. T. A. Pickett, and S. N. Handel. 2002. Probability of tree seedling establishment changes across a forest-old field edge gradient. American Journal of Botany 89: 466-471.

Muir, G., A. J. Lowe, C. C. Fleming, And C. Vogl. 2004. High nuclear genetic diversity, high levels of outcrossing and low differentiation among remnant populations of Quercus petraea at the margin of its range in Ireland. Annals of Botany 93: 691-697.

Nakanishi, A., N. Tomaru, H. Yoshimaru, T. Manabe, and S. Yамамото. 2009. Effects of seed- and pollen-mediated gene dispersal on genetic structure among Quercus salicina saplings. Heredity 102: 182-189.

Otero-Arnaiz, A., A. Casas, and J. L. Hamrick. 2005. Direct and indirect estimates of gene flow among wild and managed populations of Polaskia chichipe, an endemic columnar cactus in Central Mexico. Molecular Ecology 14: 4313-4322.

Ottewell, K. M., S. C. Donnellan, A. J. Lowe, and D. C. Paton. 2009. Predicting reproductive success of insect- versus bird-pollinated scattered trees in agricultural landscapes. Biological Conservation 142: $888-898$.

Pluess, A. R., V. L. Sork, B. Dolan, F. W. Davis, D. Grivet, K. Merg, J. PAPP, AND P. E. SMOUSE. 2009. Short distance pollen movement in a wind-pollinated tree, Quercus lobata (Fagaceae). Forest Ecology and Management 258: 735-744.

Robledo-Arnuncio, J. J., R. AliA, AND L. GiL. 2004. Increased selfing and correlated paternity in a small population of a predominantly outcrossing conifer, Pinus sylvestris. Molecular Ecology 13: 2567-2577.
Robledo-Arnuncio, J. J., F. Austerlitz, and P. E. Smouse. 2006. A new method of estimating the pollen dispersal curve independently of effective density. Genetics 173: 1033-1045.

Robledo-Arnuncio, J. J., F. Austerlitz, and P. E. Smouse. 2007. POLDISP: A software package for indirect estimation of contemporary pollen dispersal. Molecular Ecology Notes 7: 763-766.

Schnabel, A., AND J. L. Hamrick. 1990. Comparative analysis of population genetic structure in Quercus macrocarpa and $Q$. gambelii (Fagaceae). Systematic Botany 15: 240-251.

Slavov, G. T., S. Leonardi, J. Burczyk, W. T. Adams, S. H. Strauss, AND S. P. Difazio. 2009. Extensive pollen flow in two ecologically contrasting populations of Populus trichocarpa. Molecular Ecology 18: 357-373.

Smouse, P. E., R. J. Dyer, R. D. Westfall, and V. L. Sork. 2001. Twogeneration analysis of pollen flow across a landscape. I. Male gamete heterogeneity among females. Evolution; International Journal of Organic Evolution 55: 260-271.

Smouse, P. E., ANd J. J. Robledo-Arnuncio. 2005. Measuring the genetic structure of the pollen pool as the probability of paternal identity. Heredity 94: 640-649.

Steinkellner, H., S. Fluch, E. Turetschek, C. Lexer, R. Streiff, A. Kremer, K. Burg, and J. Glossl. 1997. Identification and characterization of $(\mathrm{GA} / \mathrm{CT})_{(\mathrm{n})}$ microsatellite loci from Quercus petraea. Plant Molecular Biology 33: 1093-1096.

Streiff, R., A. Ducousso, C. Lexer, H. Steinkellner, J. Gloessl, AND A. Kremer. 1999. Pollen dispersal inferred from paternity analysis in a mixed oak stand of Quercus robur L. and Q. petraea (Matt.) Liebl. Molecular Ecology 8: 831-841.

Valbuena-Carabaña, M., S. C. González-Martínez, V. L. Sork, C. Collada, A. Soto, P. G. Goicoechea, and L. Gil. 2005. Gene flow and hybridization in a mixed oak forest (Quercus pyrenaica Willd. and Quercus petraea (Matts.) Liebl.) in central Spain. Heredity 95: 457-465.

White, G. M., D. H. Boshier, AND W. Powell. 2002. Increased pollen flow counteracts fragmentation in a tropical dry forest: An example from Swietenia humilis Zuccarini. Proceedings of the National Academy of Sciences, USA 99: 2038-2042. 